\title{
Non-Destructive Investigation of a 44-Year-Old RC Structure Exposed to Actual Marine Tidal Environments Using Electrochemical Methods
}

\author{
Pinta Astuti $^{1^{*}}$, Khalilah Kamarulzaman ${ }^{2}$, Hidenori Hamada ${ }^{2}$ \\ ${ }^{1}$ Department of Civil Engineering, \\ Universitas Muhammadiyah Yogyakarta, Kasihan, Bantul, 55183, INDONESIA \\ ${ }^{2}$ Department of Civil and Structural Engineering, \\ Kyushu University, 744 Motooka, Nishi-ku, Fukuoka-shi, Fukuoka, 819-0395, JAPAN \\ *Corresponding Author
}

DOI: https://doi.org/10.30880/ijie.2021.13.03.018

Received 20 December 2020; Accepted 01 May 2021; Available online 06 June 2021

\begin{abstract}
Investigation of deterioration progress in marine structures without destroying them is crucial as early detection of damage before applying the suitable remedial measures. This study presents a series of non-destructive assessment on a 44-year-old naturally corroded RC structure exposed to marine tidal environments using observation of defective appearances and electrochemical tests. The visual observation was conducted by inspecting the corrosion condition of steel bars, crack patterns, and the spalling of concrete cover. The electrochemical investigations carried out in this research consisted of the half-cell potential mapping, the electrical resistivity of concrete, and the corrosion rate of steel bars. The results revealed that electrochemical test results conducted in this research were in good agreement with the actual deterioration degree checked by defective appearances. The RC structure was categorized as Grade II-1 (first half of the acceleration stage). Based on the deterioration degree, both applications of small direct current to control the potential of steel bars in immunity condition and patch repair method by removing the chloride contaminated concrete were recommended as appropriate repairing strategies, and they could extend the service life the of structure.
\end{abstract}

Keywords: Non-destructive test, electrochemical method, corrosion, half-cell potential, electrical resistivity

\section{Introduction}

Reinforcing bar corrosion in reinforced concrete (RC) structures exposed to marine environments is the most impactful causal factor of deterioration with potential critical repercussions on serviceability and safety [1]-[4]. The ingress of chloride ions begins the initiation of corrosion from seawater to concrete. Damage resulting from steel corrosion is manifested in expansions leading to cracking and spalling of the concrete cover. In addition to the loss of concrete cover, RC members may suffer structural damage because of the loss of bond between steel and concrete and the loss of reinforcement in the cross-section, to the extent that structural failure becomes inevitable in specific instances [5]. The correlation model between the deterioration progress and performance reduction due to corrosion on RC structures was demonstrated as a service life model by the Japan Society of Civil Engineer (JSCE) Standard 2007 [6]. The performance capacity of RC members significantly decreased when the acceleration progress indicated by cracking occurrence in concrete started. It is reported that for ordinary RC, a marine substructure can exhibit visible signs of corrosion attack in the first 12 years of exposure [7]-[9], and a tidal zone is an area with the highest corrosion risk due to the highest chloride ions accumulation during the service life of structures. Moreover, investigation of the 
deterioration progress without destroying structures in this critical stage is essential as early detection of the damage before applying appropriate maintenance measures to suppress the deterioration progress, especially in the aggressive environment such as the tidal zone.

Electrochemical tests used for investigation of corrosion were developed since several decades ago, such as halfcell potential mapping to predict the corrosion probability [10], electrical resistivity [11], linear polarization resistance (LPR) [12], [13], and an AC impedance method [14]. Many previous researchers conducted these tests applied to the artificial corrosion process in laboratory simulation due to its simplicity and shorter time required [5], [15]. Normally, the natural corrosion process requires more than a decade before affecting the structural performance, and the applicability of long-term electrochemical tests performed in the natural corrosion process exposed to several environments is not fully understood due to its complex factor. However, the advantages of the case study on the real structures are the comprehensive effects of its complex environmental factor during actual service life that can reflect the real response of structures [5]. Moreover, there is limited information from the previous researcher about the correlation of the electrochemical test results and the defective appearances of real structures aged more than 40 years exposed to marine tidal environments.

This research work, a series of non-destructive investigations, including observation of defective appearances on the RC beam and electrochemical tests on the 44-year-old structure exposed to actual marine environments, was demonstrated. The aim is to determine the applicability of the electrochemical methods to assess the deterioration stage of a more than 40-year-old of naturally deteriorated RC structure and to confirm the deterioration degree checked by defect condition. The alternative remedial measures to control the deterioration progress based on the investigation results without destroying structures are also briefly presented in the last section of this study.

\section{Structure Overview}

The detailed information of the structure, including the history of exposure condition, detail of reinforcement, and material properties used in this research is presented in this section.

\subsection{Exposure History of the Structure}

In the early age of exposure, the RC beam was moisture-cured for one day and demoulded before being air-cured. The structures were moved to exposure condition in the natural tidal marine environment for 20 years from 1975 to 1995 at Sakata Port $\left(38^{\circ} 55^{\prime} 52^{\prime \prime N} 139^{\circ} 49^{\prime} 08^{\prime \prime E}\right)$, Yamagata Prefecture, the northwestern part of Japan. In 1995-2010, the beams were sheltered from the rain and kept in a dry condition at Port and Airport Research Institute (PARI) laboratory, Yokosuka, Japan [16], [17], and exposed to Kyushu University site, Fukuoka, Japan with the natural sunny and rainy condition. The exposure conditions until 44 years were depicted in Fig. 1.

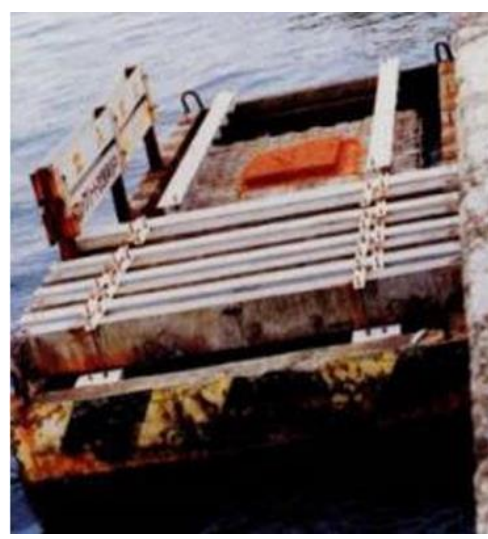

(a)

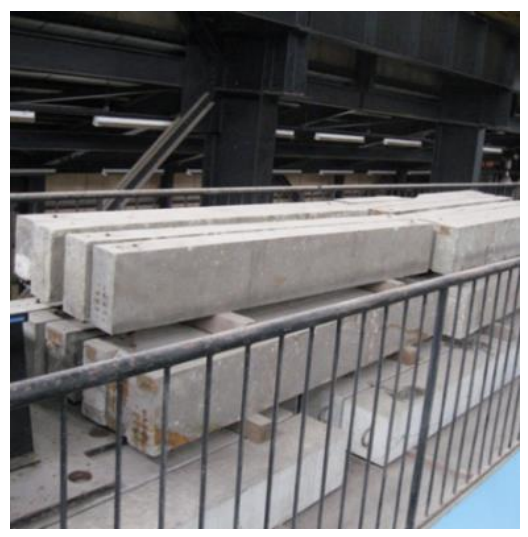

(b)

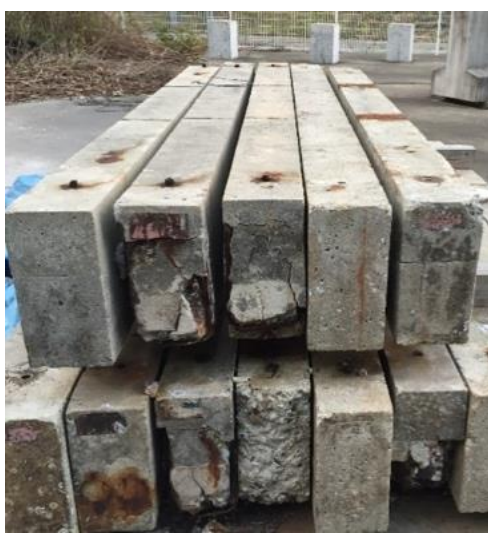

(c)

Fig. 1 - Exposure condition at (a) Sakata Port (1975-1995), (b) PARI Laboratory (1995-2010), (c) Kyushu University site (2010-2018) [16]-[18]

\subsection{Detail of the Structure}

One RC beam structure used in this research was cast in 1974. It has a length of $2400 \mathrm{~mm}$ and a cross-sectional area of $150 \mathrm{~mm}$ x $300 \mathrm{~mm}$. The typical specimens were utilized in the previous researches [18]-[21]. Longitudinally deformed steel bars with a diameter of $13 \mathrm{~mm}$ and $363 \mathrm{MPa}$ in tensile strength were embedded as tensile bars in the beam. Two round steel bars of $6 \mathrm{~mm}$ in diameter as compressive bars and stirrups with a spacing of $100 \mathrm{~mm}$ were embedded. The detailed cross-section and reinforcing bar layout are depicted in Fig. 2. 


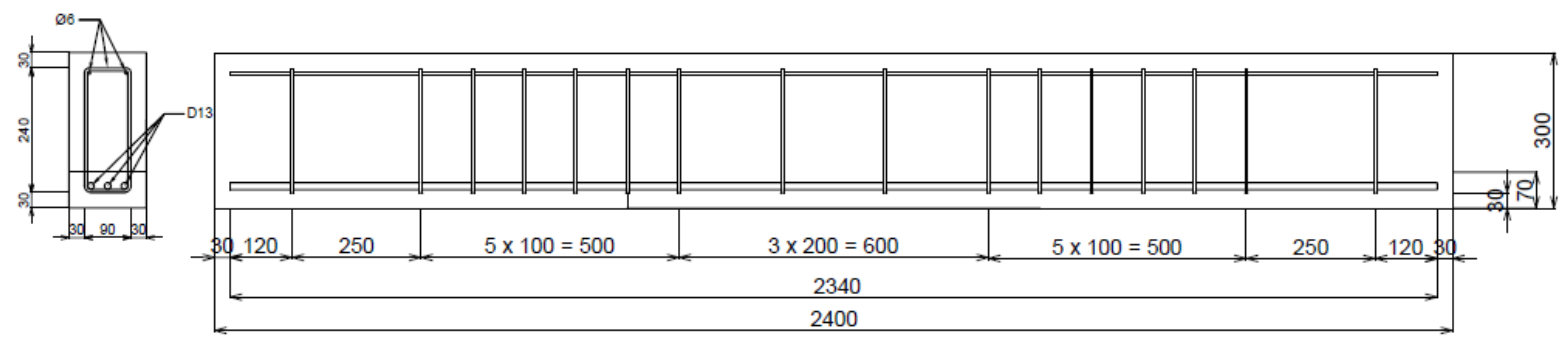

Fig. 2 - Detail of cross-section and reinforcing bar layout of the RC beam structure

\subsection{Material Properties}

Ordinary Portland Cement (OPC) was used as a binder of the concrete in this specimen. The specific gravity and fineness modulus of aggregates are summarized in Table 1. Table 2 presents the mix proportion of the existing concrete.

Table 1 - Material properties of aggregates [18]-[21]

\begin{tabular}{lcc}
\hline \multicolumn{1}{c}{ Aggregate } & Specific gravity & Fineness modulus \\
\hline Fine river sand & 2.25 & 2.84 \\
Coarse-crushed stone & 2.75 & 6.63 \\
\hline
\end{tabular}

Table 2 - Mix proportion of existing concrete [18-21]

\begin{tabular}{|c|c|c|c|c|c|c|c|c|c|}
\hline \multirow{2}{*}{$\begin{array}{l}\text { MSA } \\
(\mathrm{mm})\end{array}$} & \multirow{2}{*}{$\begin{array}{c}\text { Slump } \\
(\mathbf{m m})\end{array}$} & \multirow{2}{*}{$\begin{array}{l}\text { Air } \\
(\%)\end{array}$} & \multirow{2}{*}{$\begin{array}{c}\text { w/c } \\
\%\end{array}$} & \multirow{2}{*}{$\begin{array}{c}\text { s/a } \\
\%\end{array}$} & \multicolumn{5}{|c|}{ Unit weight (kg/m3) } \\
\hline & & & & & $\mathbf{W}$ & $\mathrm{C}$ & $\mathbf{S}$ & $\mathbf{G}$ & Adm. \\
\hline 20 & $12 \pm 2$ & $4 \pm 1$ & 68 & 47 & 204 & 300 & 793 & 964 & 1.2 \\
\hline
\end{tabular}

MSA:maximum size of coarse aggregate; W: water; C: cement; S: sand; G: gravel; Adm.: admixture

\section{Non-Destructive Investigation Method}

\subsection{Defective Appearances}

The visual observation was carried out by checking the defective appearances, such as the corrosion of reinforcing steel, cracking conditions, and the spalling of concrete cover. The assessment criterion of the deterioration stage was assessed based on Table 3. Total deterioration progress value was the total corrosion value of reinforcing steel $\left(\mathrm{X}_{1}\right)$, cracking $\left(\mathrm{X}_{2}\right)$, and spalling of concrete cover $\left(\mathrm{X}_{3}\right)$. The determination of the deterioration stage based on total deterioration progress value is presented in Table 4 .

Table 3 - Assessment criteria of deterioration stage [22]

\begin{tabular}{|c|c|c|c|c|c|c|}
\hline \multirow{2}{*}{$\begin{array}{l}\text { Evaluation } \\
\text { Items }\end{array}$} & \multicolumn{6}{|c|}{ Deterioration Degree } \\
\hline & $\mathbf{0}$ & 1 & 2 & $\mathbf{3}$ & 4 & 5 \\
\hline $\begin{array}{l}\text { Corrosion } \\
\text { of } \\
\text { reinforcing } \\
\text { steel }\left(\mathbf{X}_{1}\right)\end{array}$ & None & $\begin{array}{l}\text { Rust spots } \\
\text { found on the } \\
\text { concrete } \\
\text { surface }\end{array}$ & $\begin{array}{l}\text { Partial rust } \\
\text { stains } \\
\text { found on } \\
\text { the } \\
\text { concrete } \\
\text { surface }\end{array}$ & $\begin{array}{l}\text { Significant rust } \\
\text { staining }\end{array}$ & $\begin{array}{l}\text { Significant } \\
\text { floating rust }\end{array}$ & $\begin{array}{l}\text { Dramatically } \\
\text { increased } \\
\text { amount of } \\
\text { floating rust }\end{array}$ \\
\hline $\begin{array}{l}\text { Cracking } \\
\left(\mathbf{X}_{2}\right)\end{array}$ & None & $\begin{array}{l}\text { Partial cracks } \\
\text { found on the } \\
\text { concrete } \\
\text { surface }\end{array}$ & $\begin{array}{l}\text { Some } \\
\text { cracks }\end{array}$ & $\begin{array}{l}\text { Many cracks, } \\
\text { including some of } \\
\text { several millimeters } \\
\text { or more in width }\end{array}$ & $\begin{array}{l}\text { Many cracks } \\
\text { of several } \\
\text { millimeters } \\
\text { in width }\end{array}$ & - \\
\hline $\begin{array}{l}\text { Spalling of } \\
\text { concrete } \\
\text { cover }\left(X_{3}\right)\end{array}$ & None & None & $\begin{array}{l}\text { Partial } \\
\text { floating } \\
\text { concrete } \\
\text { found }\end{array}$ & $\begin{array}{l}\text { Partial spalling } \\
\text { found }\end{array}$ & $\begin{array}{l}\text { Significant } \\
\text { spalling }\end{array}$ & $\begin{array}{l}\text { Drastic } \\
\text { spalling }\end{array}$ \\
\hline
\end{tabular}


Table 4 - Deterioration state based on deterioration progress value

\begin{tabular}{cl}
\hline $\begin{array}{c}\text { Deterioration progress value } \\
\left(\sum \mathbf{X}\right)\end{array}$ & \multicolumn{1}{c}{ Deterioration State } \\
\hline $\mathbf{0}$ & I-1 (Initiation stage, no defect found in appearance) \\
\hline $\mathbf{1}<\sum \mathbf{X}<\mathbf{3}$ & $\begin{array}{l}\text { I-2 (Propagation stage, no defect found in appearance and } \\
\text { corrosion starts) }\end{array}$ \\
\hline $\mathbf{3}<\sum \mathbf{X}<\mathbf{6}$ & $\begin{array}{l}\text { II-1 (First half of the acceleration stage, cracking occurs due to } \\
\text { corrosion) }\end{array}$ \\
\hline $\mathbf{6}<\sum \mathbf{X}<\mathbf{9}$ & $\begin{array}{l}\text { II-2 (Second half of the acceleration stage, with the progress of } \\
\text { cracking due to corrosion, peeling or spalling is found and no } \\
\text { cross-section loss of the steel bar) }\end{array}$ \\
\hline $\mathbf{9}<\sum \mathbf{X}<\mathbf{1 2}$ & $\begin{array}{l}\text { III (Deterioration stage, peeling and spalling are found with } \\
\text { cracking due to corrosion and cross-section loss of the steel bar) }\end{array}$ \\
\hline$>\mathbf{1 2}$ & Degradation stage \\
\hline
\end{tabular}

\subsection{Electrochemical Tests}

Several electrochemical assessment methods were conducted in this study, including half-cell potential, the electrical resistivity of concrete, and the corrosion rate of the steel bar. All electrochemical measurements require several preparations, such as identification of steel bar location, creating a connection of steel bar, and concrete surface preparation through wetting.

Half-cell potential mapping of steel bar according to ASTM C876-15 [10] was conducted to test the corrosion probability using a saturated calomel electrode (SCE) and a high impedance multimeter (voltmeter setting) on every 50 $\mathrm{mm}$ square grid after one hour of pre-wetting. The reference electrode was connected to the negative terminal and the reinforcing bar to the positive terminal of the multimeter [23]. The schematic measurement setting of half-cell potential is presented in Fig. 3. The determination value is tabulated in Table 5.

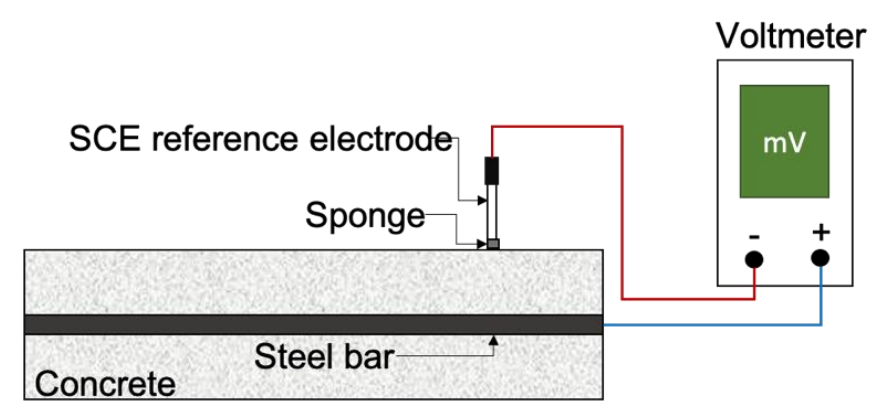

Fig. 3 - Schematic measurement method of the half-cell potential test

Table 5 - Determination of corrosion probability [10]

\begin{tabular}{cc}
\hline $\begin{array}{c}\text { Half-cell potential }(\mathbf{E}) \\
(\mathbf{m V} ; \mathbf{C S E})\end{array}$ & Corrosion probability \\
\hline $\mathbf{E}>\mathbf{- 2 0 0}$ & $90 \%$ no corrosion \\
\hline $\mathbf{- 3 5 0}<\mathbf{E}<-\mathbf{2 0 0}$ & Uncertainty \\
\hline $\mathbf{E}<\mathbf{- 3 5 0}$ & $90 \%$ corrosion \\
\hline
\end{tabular}

The electrical resistivity of concrete is described as the ability of charge transport properties of the pore system in concrete. The concrete electrical resistivity can be obtained by applying a current into concrete and measuring the response voltage. In this study, it was measured using four electrodes, as presented in Fig. 4. The two end electrodes were used to inject current, and the voltage was measured between the two inner electrodes. The resistivity of the concrete $\rho$ was calculated as $\rho=2 \pi a R$, where a was the effective distance between two inner electrodes and R was resistance calculated using different voltage divided by different current. The determination value of electrical resistivity value is presented in Table 6 .

The corrosion rate of the steel bar expressed using corrosion current density in this research was measured using a portable corrosion meter based on the AC impedance principle. Silver chloride electrode (SSE) was used as a reference electrode. The schematic measurement method is depicted in Fig. 5, and the corrosion risk probability is presented in Table 7 . 


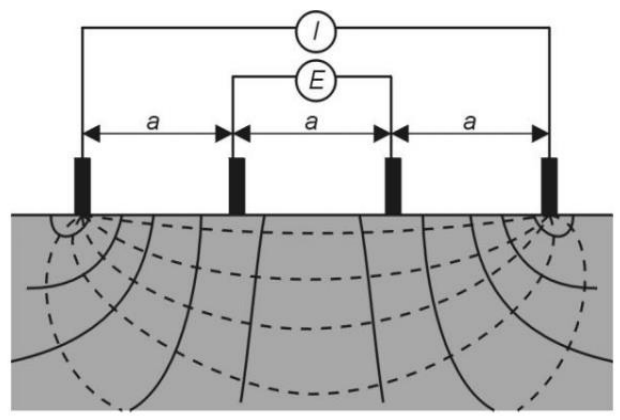

Fig. 4 - Scheme of Wenner technique to check electrical resistivity of concrete [11], [24]

Table 6 - Determination of electrical resistivity [11], [24]

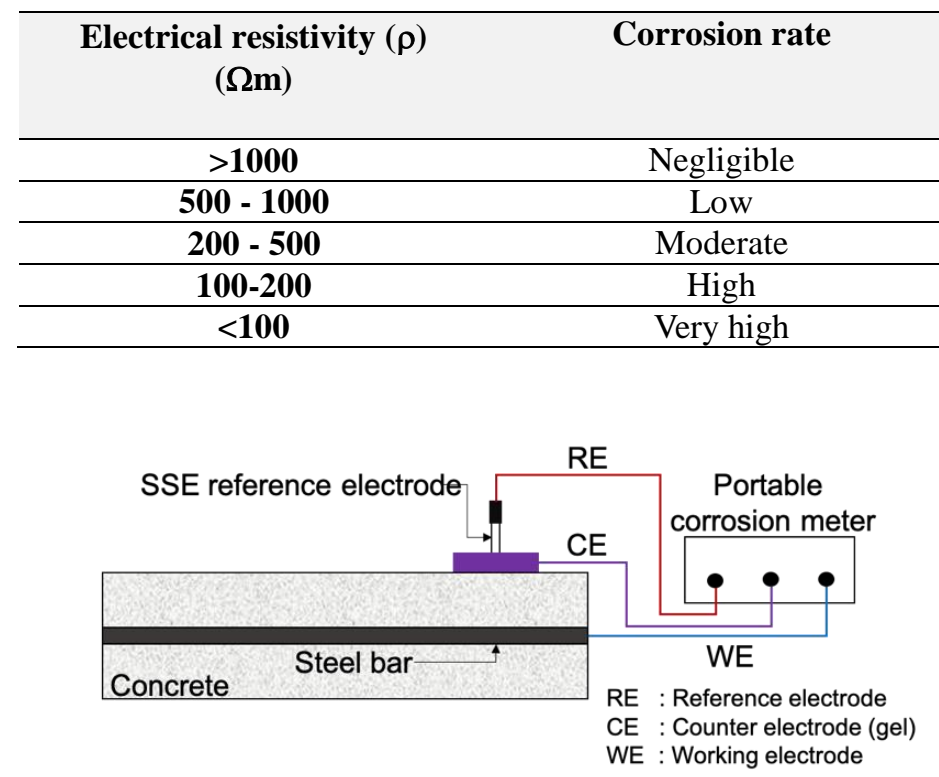

Fig. 5 - Schematic measurement method of the corrosion rate test

Table 7 - Corrosion risk based on the corrosion rate (corrosion current density) [11]

\begin{tabular}{cc}
\hline $\begin{array}{c}\text { Corrosion current density } \\
\left(\mu \mathbf{A} / \mathbf{m}^{2}\right)\end{array}$ & Corrosion risk \\
\hline$>\mathbf{1 . 0}$ & Severe / very high \\
\hline $\mathbf{0 . 5}-\mathbf{1 . 0}$ & Moderate to high \\
\hline $\mathbf{0 . 2}-\mathbf{0 . 5}$ & Low to moderate \\
\hline $\mathbf{0 . 1}-\mathbf{0 . 2}$ & Low \\
\hline$<\mathbf{0 . 1}$ & Passive state \\
\hline
\end{tabular}

\section{Results and Discussion}

\subsection{Defective Appearances}

The defective appearance observation of the RC structure was conducted on severe cracks, rust stains, chips, and air bubbles. Fig. 6 depicts the correlation between defective appearance and the half-cell potential value. There appeared rough surfaces, chips on the edges, and few small spalling on the RC beam. The visual inspection revealed no significant degradation for the RC structure with $3 \mathrm{~cm}$ of cover thickness after 44 years of exposure, indicating that the thickness was enough to be used to the specimen exposed to the marine environment in its first 20-years of exposure.

The cracks occurred in the concrete surface were observed on all sides. The specimen presented cracks alongside the beam parallel to rebar, and most of the cracking occurred in the middle tensile area. Numerous longitudinal and transversal cracks in both the tensile and compressive areas were visible. This RC beam showed severe damage visually than other beams. Therefore, the corrosion caused the cracks along the reinforcement. 
These longitudinal cracks coincided with the positions of the tensile and the compressive rebar. The transversal cracks concentrated in the middle span of the tensile area were initiated from the pre-cracking due to stirrup corrosion [18]. The maximum crack width in this beam surface was $9.5 \mathrm{~mm}$, and $11 \mathrm{~mm}$ was the maximum crack depth measured using an ultrasonic pulse velocity (UPV) apparatus [26], as presented in Fig. 10. Air bubbles of 1 17 mm in diameter also appeared on the beam surface.

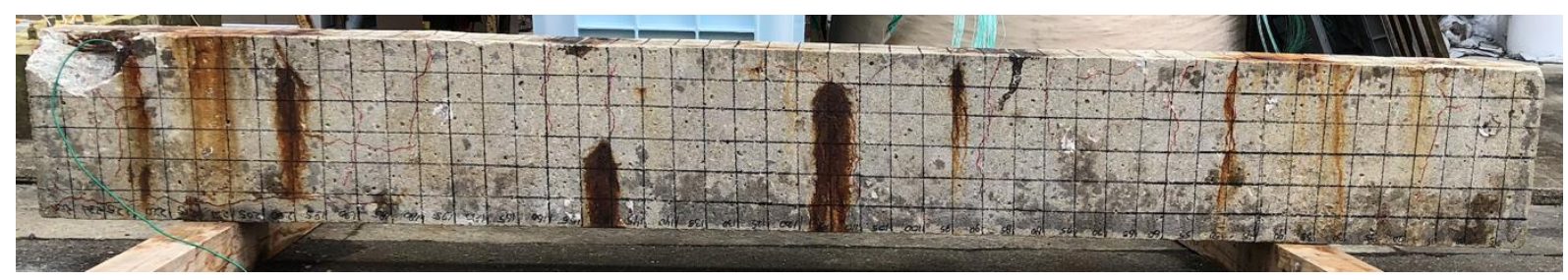

Fig. 6 - Defective appearances of the RC beam

The deterioration progress value of the RC beam was assessed using the criteria from Table 3 . The corrosion condition of reinforcing steel $\left(\mathrm{X}_{1}\right)$ in this specimen was " 2 ", in which partial rust stain was found on the concrete surface. The cracking condition $\left(\mathrm{X}_{2}\right)$ was " 3 " where numerous cracks, including some of several millimeters or more in width, were discovered. No spalling of the concrete cover was found; thus, it was " 0 " for $\mathrm{X}_{3}$. The spalling on the lefttop part in Fig. 6 occurred during making a steel bar connection for the measurement process. The total deterioration progress value of the specimen was " 5 " and based on Table 4, it was categorized as Grade II-1, the first half of the acceleration stage. The detail of deterioration progress value is tabulated in Table 8.

Table 8. Deterioration progress value of the specimen

\begin{tabular}{lc}
\hline \multicolumn{1}{c}{ Evaluation Items } & $\begin{array}{c}\text { Deterioration Progress } \\
\text { Value }\end{array}$ \\
\hline Corrosion of reinforcing steel $\left(\mathbf{X}_{\mathbf{1}}\right)$ & 2 \\
\hline Cracking $\left(\mathbf{X}_{\mathbf{2}}\right)$ & 3 \\
\hline Spalling of concrete cover $\left(\mathbf{X}_{\mathbf{3}}\right)$ & 0 \\
\hline Total deterioration progress value $\mathbf{= 5}$ &
\end{tabular}

\subsection{Electrochemical Assessment}

\subsubsection{Half-Cell Potential of Rebar}

Fig. 7 presents the half-cell potential value of tensile and compressive rebars. Tensile rebar 1 and compressive rebar 1 were located on the front surface. The rebars embedded in the back surface were denoted as tensile rebar 2 and compressive rebar 2. Generally, the values of half-cell potential in all cross-sectional parts were in the "uncertainty" region, and it was between $-350 \mathrm{mV}$ and $-200 \mathrm{mV}$ vs. CSE. Either two tensile rebars or two compressive rebars presented similar potential trends. However, a quarter length of compressive rebars showed lower potential than others, which was less than $-300 \mathrm{mV}$ vs. CSE. The uniformity of half-cell potential value of specimen was affected by several factors such as non-homogeneous material quality after 44 years of exposure, chloride content, water content during measurement, and crack condition around the measurement point. The state of "uncertainty" of corrosion probability was observed as the RC beam was kept in a dry condition. Hence, the corrosion probability decreased during the absence of water content. It would significantly decrease in the $90 \%$ corrosion region if the specimen interacted with water. Previous experiments showed that the corrosion probability of typical RC specimens stated the " $90 \%$ corrosion" probability and the half-cell potential value below $-350 \mathrm{mV}$ vs. CSE $[19,20]$ due to the specimens were measured in the wet condition during the rainy season.

\subsubsection{Electrical Resistivity of Concrete}

The electrical resistivity test was conducted using a four-electrode method developed by Wenner, and the principal is presented in Fig. 4. The measurement points were at $28 \mathrm{~cm}, 68 \mathrm{~cm}, 120 \mathrm{~cm}, 175 \mathrm{~cm}$, and $213 \mathrm{~cm}$ distance from the edge with vertical direction, and it should avoid longitudinal bar positions to prevent the measured value affected by steel. The results are presented in Fig. 8. The resistivity of concrete at the left edge until middle span length was between $100 \Omega \mathrm{m}$ and $200 \Omega \mathrm{m}$ and it was categorized as "high risk" corrosion. Only at $175 \mathrm{~cm}$ and $213 \mathrm{~mm}$ from the edge were more than $200 \Omega \mathrm{m}$, and it was "moderate" corrosion risk. The electrical resistivity of concrete was described as the ability of concrete to withstand the transfer of ions subjected to an electrical field. In concrete durability context, electrical resistivity measurement could be used to assess the chloride ions movement inside of concrete, causing corrosion initiation. The state of "high risk" showed that the pore of concrete could transfer more chloride ions. The 
results of electrical resistivity performed the same tendency with the result of half-cell potential value demonstrated in Fig. 7.

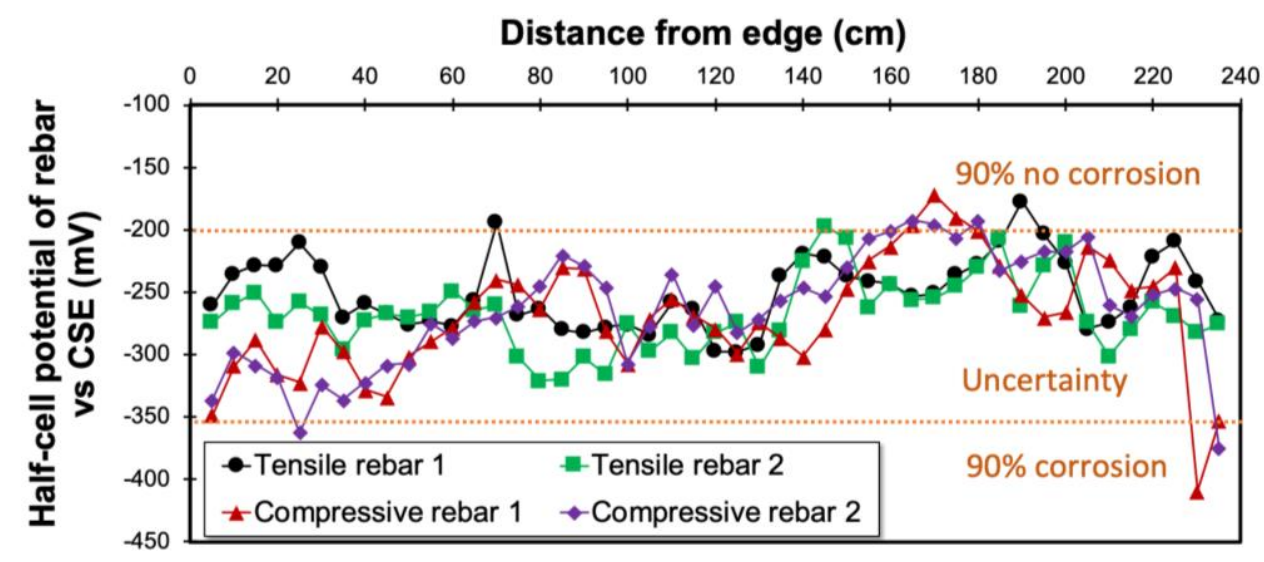

Fig. 7 - Half-cell potential value of tensile and compressive rebars

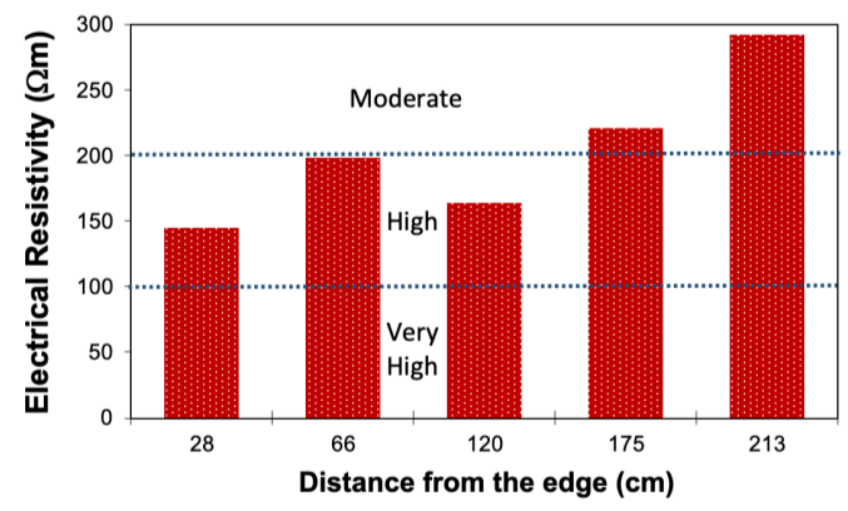

Fig. 8 - Electrical resistivity of concrete

\subsubsection{Corrosion Current Density of Steel Bar}

The corrosion rate can be measured using a corrosion current density of the steel bar. Meanwhile, the AC impedance principle method was used to assess the corrosion current density in this experiment. The results are presented in Fig. 9. The corrosion rate in the tensile steel bar is higher than that in the compressive steel bar. The passivity limit is generally defined as a corrosion current density of $0.1 \mu \mathrm{A} / \mathrm{cm}^{2}$ [25]. The tensile steel bar was on the "low" corrosion risk, and the compressive steel bar was on the "passive state". The first data on the compressive steel bar was checked on the spalling area when creating a wire connection to the steel. Thereby, it shows different trend data.

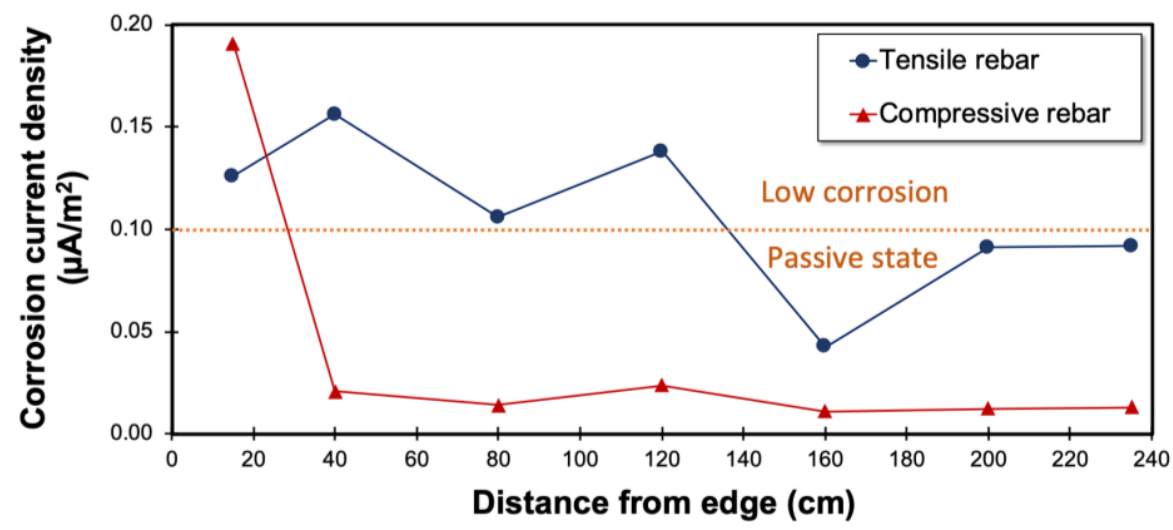

Fig. 9 - Corrosion current density of tensile and compressive rebars 


\subsection{Correlation of Defective Appearance and Corrosion Map}

Almost all concrete surfaces were in more negative than $-200 \mathrm{mV}$ of half-cell potential, meaning that the corrosion probability of the rebar from all surfaces was in "uncertainty" based on ASTM C876-15. The potential of some areas was more than $-350 \mathrm{mV}$ vs. CSE, which was in the " $90 \%$ corrosion" condition. The severe corrosion probability was in line with the occurrence of physical damage such as cracks and rust stain, as presented in Fig. 10. The maximum crack width of the specimen was $2.20 \mathrm{~mm}$ in line with the middle tensile steel bar. Generally, the crack width observed in this specimen was more than $0.3 \mathrm{~mm}$, the maximum allowable crack based on the JSCE maintenance standard [6]. The maximum crack depth of this RC beam was $13 \mathrm{~cm}$, meaning that it was more than the concrete cover thickness. Therefore, the chloride easily penetrated to the steel bar surface. The higher corrosion probability was in the position of the surface area with larger cracks width. Based on the corrosion map, crack condition, and other defective appearances, the most severely damaged part was on the middle tensile part, marked with a green rectangle.

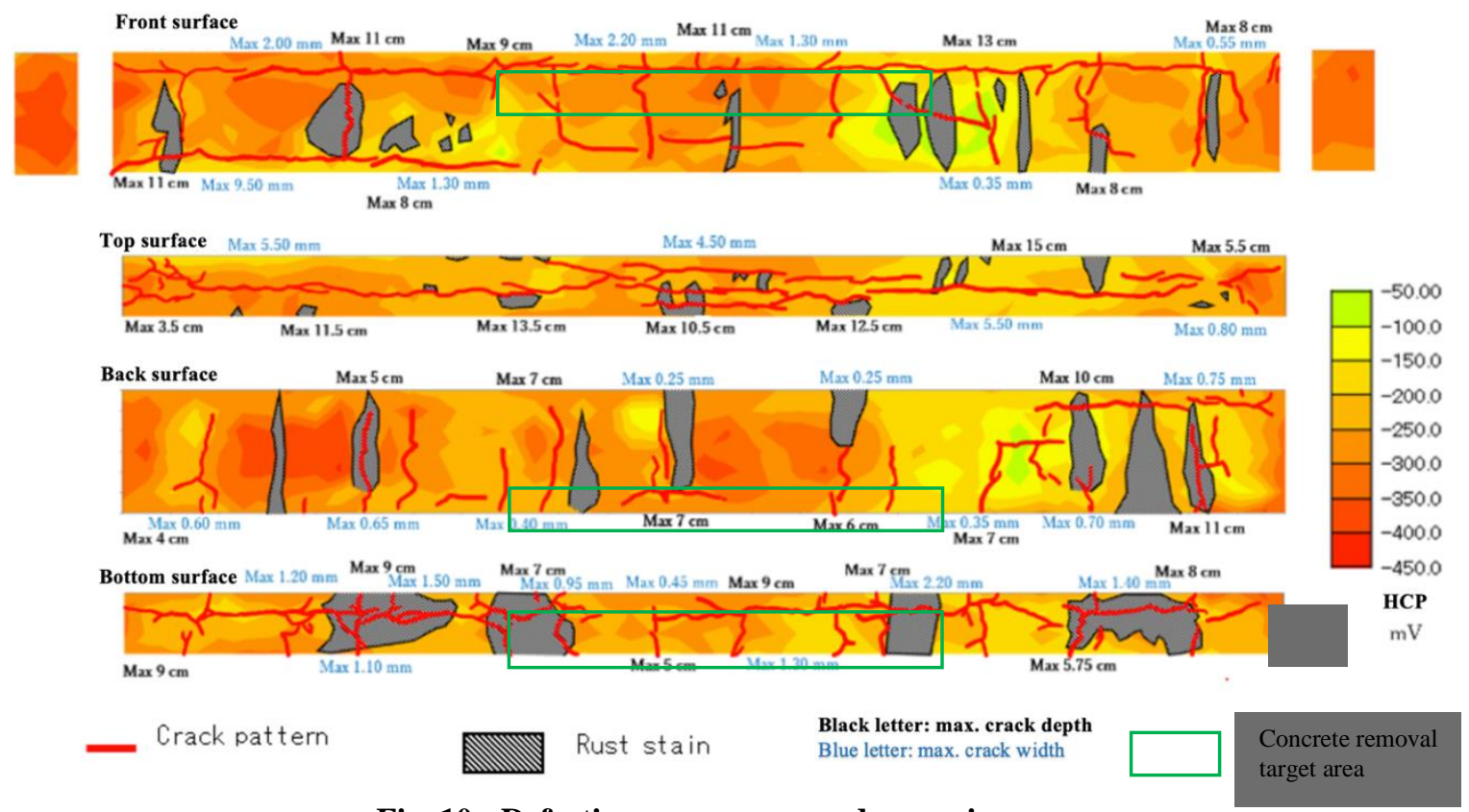

Fig. 10 - Defective appearance and corrosion map

\section{Alternative Remedial Measures}

Based on the results of defective appearances and electrochemical measurements, the alternative repair design of the RC beam is presented in Fig. 11. It was necessary to replace the most severely damaged part with the new repair material. The polymer-modified mortar could be applied in the middle of the tensile area. The area with low half-cell potential value and in " $90 \%$ corrosion" condition, but without material replacement, required a sacrificial anode cathodic protection method to shift the potential in to "immunity" value. This remedial model could be used to extend the service life of the RC structure, as explained by previous research [18], [27].
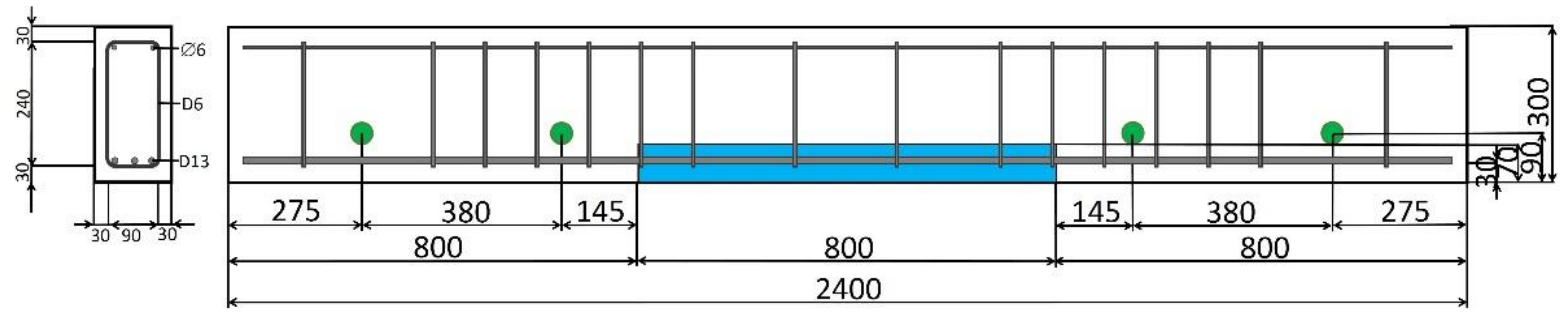

Fig. 11 - Alternative repair design for the deteriorated $\mathrm{RC}$ beam

\section{Conclusions}

Based on the experimental program in this study, several conclusions were derived as follows.

- The electrochemical tests applied on the 44-year-old naturally damaged RC structure exposed to the marine tidal environment, including half-cell potential mapping, the electrical resistivity of concrete, and corrosion rate, were in good agreement with the actual deterioration assessment using visual observation. 
- The electrochemical tests without destroying structures could be used as investigation methods to assess the deterioration state of the RC structure before applying remedial measures to extend the service life.

- The deterioration degree of the RC beam used in this study was categorized as Grade II-2 (second half of the acceleration stage). Both applications of small direct current to control the potential of the steel bar in immunity condition and patch repair method by removing the chloride contaminated concrete were recommended as appropriate repairing strategies, extending the structure service life.

\section{References}

[1] American Concrete Institute (2000). Service-Life Prediction - State of Art Report. ACI 365

[2] Bertolini L. (2008). Steel corrosion and service life of reinforced concrete structures. Structure and Infrastructure Engineering, 4, 123-137

[3] Winston R. R. (2000). Uhlig's Corrosion Handbook. The Electrochemical Society

[4] Bossio A., Monetta T., Bellucci F., Lignola G. P. \& Prota A. (2015) Modeling of concrete cracking due to corrosion process of reinforcement bars. Cement and Concrete Research, 71, 78-92

[5] Loreto, G., Di Benedetti, M. D., De Luca, A., and Nanni, A. (2018) Assessment of reinforced concrete structures in marine environment: a case study. Corrosion Reviews, 0,0

[6] Japan Society of Civil Engineer (2007). JSCE Standard Specification For Concrete Structures Part: Maintenance.

[7] Saguez A., Powers R. \& Zayed A. (1990). Marine environment corrosion of epoxy-coated reinforcing steel. Proceeding of the $3^{\text {rd }}$ International Symposium on Corrosion of reinforcement of Concrete Construction, pp. 539549

[8] Scannel W. T. \& Sohanghpurwala A. A. (1992). Rehabilitation of reinforced concrete balconies on a multi-story condominium in South Florida. Proceeding of Corrosion 92, NACE International, 202, 1-19

[9] Krauss P. D. \& Nmai C. K. (1996). Preliminary investigation of prestressed concrete piles in a marine environment. Deerfield Beach Fishing Pier, ASTM, STP, 1276, 162-170

[10] ASTM C876-15 2015 (2015). Standard Test Method for Half-Cell Potential of Reinforcing Steel in Concrete. American Society for Testing and Materials

[11] Comité Euro International du Béton. (1989) Durable Concrete Structures - CEB Design Guide. Bulletin D'Information, 182, 102-116

[12] Brown D. W., Connolly R. J., Laskowski B., Garvan M., Li, H., Agarwala V. S. \& Vachtsevano G. (2014). A novel linear polarization resistance corrosion sensing methodology for aircraft structure. Proceeding Annual Conference of the Prognostics and Health Management Society, pp. 298-308

[13] Ahmad S., Jibran M. A. A., Azad A. K. \& Maslehuddin M. (2014). A simple and reliable setup for monitoring corrosion rate of steel rebars in concrete. Scientific World Journal, 2014, 525678

[14] Ismail M. \& Ohtsu M. (2006). Corrosion rate of ordinary and high-performance concrete subjected to chloride attack by AC impedance spectroscopy. Construction and Building Material, 20, 458-469

[15] Altoubat S., Maalej M. \& Shaikh F. U. A. (2016). Laboratory simulation of corrosion damage in reinforced concrete. International Journal of Concrete Structures and Materials, 10, 383-391

[16] Hamada H., Otsuki N. \& Haramo M. (1988). Durability of concrete beams under marine environments exposed in port of Sakata and Kagoshima (after 10 year's exposure). Technical Note of the Port and Airport Research Institute, 614, 3-43

[17] Yokota H., Akiyama T., Hamada H., Mikami A. \& Fukute T. (1999). Effect of degradation of concrete on mechanical properties of reinforced concrete beams exposed to marine environment (for 20 years in Sakata). Report of the Port and Airport Research Institute, 38, 2-32

[18] Astuti P., Rafdinal R. S., Mahasiripan A., Hamada H., Sagawa Y. \&Yamamoto D. (2018). Potential development of sacrificialnode cathodic protection applied for severely damaged RC beams aged 44-years. Journal of Thailand Concrete Association, 6, 24-31

[19] Rafdinal R. S. (2016). Life extension of RC structure by cathodic protection using zinc sacrificial anode embedded in concrete. PhD Thesis, Kyushu University

[20] Dasar A., Hamada H., Sagawa Y. \& Yamamoto D. (2017). Deterioration progress and performance reduction of 40-year-old reinforced concrete beams in natural corrosion environment. Construction and Building Materials, $147,690-704$

[21] Astuti P. (2020). A study on repair strategy of severely damaged rc structures by using sacrificial anode cathodic protection. PhD Thesis, Kyushu University

[22] Yokota H., Fukute T., Hamada H. \& Akiyama T. (1999) Structural assessment of deteriorated RC and pc beams exposed to marine environment for more than 20 years. Wakachiku Kensetsu Doboku Gijutsu Nenpo, 8, 78-84.

[23] Elsener B. (2003). Half-cell potential measurements - potential mapping on reinforced concrete structures. RILEM TC 154-EMC: 'Electrochemical Techniques for measuring metallic corrosion'. Material and Structures, $36,461-471$ 
[24] Layssi H., Ghods P., Alizadeh A. R. \& Salehi M. (2015). Electrical resistivity of concrete. Concrete International, $37,41-46$

[25] Alonso C., Castellote M. \& Andrade C. (2002). Chloride threshold dependence of pitting potential of reinforcement. Electrochemia Acta, 47, 3447-3469

[26] ASTM C 5972002 (2002). Standard Test Method for Pulse Velocity Through Concrete. American Society for Testing and Materials

[27] Astuti P., Rafdinal R. S., Kamarulzaman K., Hamada H., Sagawa Y. \& Yamamoto D. (2019). Repair method of deteriorated RC beams by sacrificial anode cathodic protection and corrosion inhibitor. Proceeding of 3rd ACF Symposium 2019 Assessment and Intervention of Existing Structures, Sapporo 